SCJR 16, no. 1 (2021): 1-3

\title{
Benjamin E. Fisher Amsterdam's People of the Book: Jewish Society and the Turn to Scripture in the Seventeenth Century
}

\author{
(Cincinnati: Hebrew Union College Press, 2020), 318 pages.
}

\author{
JOSEPH DAVIS \\ jdavis@gratz.edu \\ Gratz College, Melrose Park, PA 19027
}

In the modern period, historical criticism has had two contrary uses. Since Spinoza, it has often been used as a basis for rejecting the authority of Scripture. But since Luther, it has also been used to defend claims of Scriptural authority and to support efforts at religious reforms. Moreover, Christians have not confined their efforts to their own religion, but have sometimes sought to intervene in favor of reforms to Judaism; Jews, in a smaller but still important way, have done the same to Christianity.

Fisher's book is set in mid-1600's Amsterdam, among a young Spanish-Portuguese Jewish community. They were descendants of conversos (Jewish converts to Christianity) from Spain and Portugal who fled the Inquisition and went to Amsterdam. Fisher's book argues convincingly that this very distinctive community of Jews approached the Bible in a different way from other Jewish communities of the time. They foreshadowed both later trends of skepticism about the Bible and a later turn toward the Hebrew Bible in modern Judaism. Amsterdam Jews also developed a new and distinctive view of "true" unitarian Christianity and of Jesus.

Fisher focuses on two leaders of the Amsterdam Jewish community, Menasseh ben Israel and Saul Morteira. Menasseh is famous for, among other things, his contacts with Rembrandt. Morteira is mainly known for signing the writ of excommunication against the philosopher Baruch Spinoza. Spinoza's TheologicalPolitical Treatise, published in 1670, laid the groundwork for modern biblical criticism, and Spinoza would become the first Western philosopher to openly reject the authority of Scripture. Fisher argues that Menasseh and Morteira, as well as Spinoza, were all committed to intense study of Scripture and humanist historical study and cultivated similar contacts with contemporary radical Christians.

Menasseh ben Israel's main study of Scripture was a voluminous work, The Conciliador, analyzed carefully by Fisher, that listed Scriptural verses that contradict one another and to which he offered harmonizing solutions. Menasseh (and 
Fisher) focused particular attention on the Biblical chronology of the kings of Israel and Judah, which includes counts of years that are difficult to reconcile.

It has frequently been observed that Menasseh's readers, if they rejected Menasseh's sometimes strained efforts at harmonization, would find an arsenal of proofs that the Bible frequently contradicts itself and therefore cannot be literally true. Indeed, Spinoza seems to have done just that. What then inspired Menasseh to work so assiduously on a book that could so easily be put to heterodox uses? It must be, Fisher argues, that many Amsterdam Jews were already troubled by these contradictions. They were influenced, Fisher argues convincingly, by new (modern) assumptions about fact, truth, and certainty, such as the insistence that columns of numbers must add up precisely.

Equally important are the writings of Saul Morteira. Morteira is a less studied figure; here Fisher breaks new ground. Morteira, Fisher argues, began his time in Amsterdam in the 1620's as a bitter opponent of Christianity. However, as Fisher shows, by the time Morteira wrote a later work, in 1660, he had developed a very different attitude. Fisher emphasizes, by way of explanation, a passage in which Morteira describes a conversation, around 1635, with an unnamed Christian scholar who was a Socinian (i.e., an Anabaptist or Unitarian). Morteira was so delighted, Fisher writes, at his discovery of Unitarian Christians that his entire attitude towards Christianity was transformed.

In his 1660 book, Morteira continued to defend Judaism and to argue against Christianity. Indeed, one section of his new polemic sharply critiques the New Testament. Much as Spinoza would do to the Hebrew Bible just ten years later, Morteira used historical analysis of the authorship of the New Testament to attack the work's authority. Morteira also argued that what many considered to be Christian doctrines such as the virgin birth, deicide, and the Trinity, were later accretions to Christianity and based on pagan beliefs. (Fisher does yeoman's work tracing the sources of Morteira's data about early Christians, Gospel authors, and pagan religion.)

But Morteira's new book did not merely polemicize against the New Testament and Christianity. It also pointed in the direction of a new reading of the New Testament and a new conception of the historical Jesus. In rejecting major parts of the New Testament, Christians would - this was the prize that Morteira offered them, as Spinoza later would as well — draw closer to Jesus himself. As Morteira saw it, they should reject the notion that Jesus believed the pagan, non-Jewish, and non-rabbinic doctrines foisted on him by the untrustworthy Gospel authors.

Morteira's Jesus was not Spinoza's Jesus. Spinoza depicted Jesus as a sort of philosopher, the proponent of a universal ethic of loving one's neighbor, an ethic that all humankind should accept. Morteira's Jesus, by contrast, is a faithful rabbinic Jew, teaching obedience to the Torah and agreeing with the rabbis on nearly all points. Building on his Jewish predecessors in the Middle Ages, whose works Fisher also analyzes carefully, Morteira constructed a picture of Jesus the Jew.

Fisher is not certain whether Spinoza was ever Morteira's student, nor can he prove that Spinoza read Morteira's 1660 polemic. But that does not matter. As Fisher shows, Morteira and Spinoza used the same tools of historical criticism, 
Spinoza against the authority of the Hebrew Bible, Morteira against the New Testament. Both were influenced by their contacts with Amsterdam's most radical Christians and both distinguished the teachings of Jesus from those of the New Testament.

Seventeenth century Amsterdam was the center of Europe, and it was there that modern science and modern liberal democracy took form. These created new questions of Scriptural interpretation, Scriptural authority, and Jewish-Christian relations. Anyone who is interested in the history of Bible interpretation or the history of Jewish-Christian relations should thank Fisher for this excellent, carefully researched work. He uncovers a crucial moment in which both the most orthodox of rabbis and the most freethinking of philosophers dreamed of a new Christianity that, drawing closer to the historical Jesus, would become friendlier towards Jews. 